\title{
Mailstop Code
}

National Cancer Institute

\section{Source}

National Cancer Institute. Mailstop Code. NCI Thesaurus. Code C87190.

A unique routing code used by a company or organization for internal mail delivery. 